\title{
CHARACTERISATION OF LOW-FREQUENCY SEA LEVEL OSCILLATIONS IN THE MEDITERRANEAN SEA
}

\section{DOLOČANJE NIZKOFREKVENČNEGA NIHANJA MORSKE GLADINE V SREDOZEMSKEM MORJU}

\author{
Vesna Bertoncelj ${ }^{1}$, Matjaž Ličer², Dušan Žagar1, ${ }^{*}$, Davide Bonaldo $^{3}$ \\ ${ }^{1}$ Univerza v Ljubljani, Fakulteta za gradbeništvo in geodezijo, Jamova 2, 1000 Ljubljana \\ ${ }^{2}$ Nacionalni inštitut za biologijo, Morska biološka postaja Piran, Fornače 41, 6330 Piran \\ ${ }^{3}$ Institute of Marine Sciences, National Research Council of Italy, Castello 2737/F, 30122 Venice, Italy
}

\begin{abstract}
Implementing adequate defences for low-lying coastal area against coastal flooding requires thorough knowledge of all potential influences leading to increased sea levels, including low-frequency sea level oscillations. We present and describe several methods applicable for the analysis of low-frequency sea level oscillations in the Mediterranean Sea: wavelet analysis, spectral analysis, moving-periodogram analysis, and rotary spectral analysis. These methods were applied for characterisation of subinertial sea level oscillations with periods greater of the period of inertial oscillation (18 hours in the Northern Adriatic Sea) on measured sea surface elevations and current velocities in the Mediterranean Sea. Preliminary analysis was performed on observations of a storm event in the Adriatic Sea at the end of January and the beginning of February 2014, revealing a peak in the frequency spectrum in the frequency band between $0.3-0.4$ day $^{-1}$. Further analysis was done on long-term tide gauge measurements available for 62 stations in the Mediterranean basin. The application of the selected methods provided a preliminary set of seasonal occurrences and durations of subinertial oscillation. This sets the ground for further investigation into the propagation of low-frequency sea level oscillations throughout the Mediterranean basin and for characterisation of the mechanisms triggering the process, including with regard to climate change.
\end{abstract}

Keywords: sea level oscillations, subinertial oscillations, Adriatic Sea, Mediterranean Sea, wavelet analysis, spectral analysis, moving periodogram

\section{Izvleček}

Ustrezni ukrepi za zaščito nižjeležečih obalnih območjih pred poplavami morja zahtevajo široko poznavanje vseh potencialnih dejavnikov, ki vplivajo na porast gladine morja, vključno z nizkofrekvenčnimi nihanji morske gladine. Med številnimi metodami smo izbrali in prikazali uporabo valčne analize, spektralne analize, analize drsečega periodograma ter rotacijske spektralne analize. Te metode smo uporabili za določanje značilnosti subinercialnega nihanja morske gladine s periodo večjo od periode inercialnih nihanj (18 ur v severnem Jadranskem morju) v Sredozemskem morju na merjenih podatkih morske gladine in morskih tokov.

\footnotetext{
*Stik / Correspondence: dusan.zagar@fgg.uni-lj.si

(C) Bertoncelj V. et al.; Vsebina tega članka se sme uporabljati v skladu s pogoji licence Creative Commons Priznanje avtorstva Nekomercialno - Deljenje pod enakimi pogoji 4.0.

(c) Bertoncelj V. et al.; This is an open-access article distributed under the terms of the Creative Commons Attribution - NonCommercial - ShareAlike 4.0 Licence.
} 
S preliminarno analizo, izvedeno na podatkih izbranega neurja na Jadranskem morju ob koncu januarja in $\mathrm{v}$ začetku februarja 2014, smo določili frekvenčni pas nihanja med $0,3-0,4 \mathrm{dan}^{-1}$. Nadaljnjo analizo smo izvedli na večletnih merjenih podatkih morske gladine za 62 merilnih mest v Sredozemskem morju. Z uporabo naštetih metod smo pridobili preliminarne rezultate, sezonsko pojavljanje in trajanje subinercialnega nihanja. Pridobljeni rezultati so lahko izhodišče za nadaljnje raziskave širjenja signala po celotnem območju Sredozemskega morja in za določanje mehanizmov, ki sprožijo subinercialno nihanje, tudi z vidika podnebnih sprememb.

Ključne besede: nihanje morske gladine, subinercialno nihanje, Jadransko morje, Sredozemsko morje, valčna analiza, spektralna analiza, drseči periodogram.

\section{Introduction}

Due to growing awareness of potential threats affecting coastal cities, thorough knowledge of all the factors causing an increase in sea level is required in order to provide accurate forecasts of coastal flooding, proper design of coastal defences, and for the implementation of adequate countermeasures. In low-lying coastal cities such as Venice (Italy) and Piran (Slovenia) along the Adriatic coast, an increase of just a few centimetres could lead to incremental flooding, causing damage to both private and public property, as well as to cultural heritage. The most intense occurrence of the well-known flooding in Venice, called acqua alta, is prevailingly caused by the coincident arrival of high tide, the peak of the wind-induced Adriatic seiche, and the south-easterly wind and wave setup. These factors are additionally complemented by the inverted barometer sea level adjustment during the passage of a pressure low, amounting to about $\partial \mathrm{h} / \partial \mathrm{p}$ $=-1 \mathrm{~cm} / \mathrm{mbar}$. Furthermore, several kinds of subinertial sea level oscillations (i.e. sea level oscillations with periods greater than the period of inertial oscillation, which equals 18 hours in the Northern Adriatic Sea) can affect the coastal zones and contribute to increased water levels.

Awareness about the vulnerability of increasingly inhabited coastal zones to flooding and sea level rise, particularly under changing climate conditions, has resulted in a relevant number of permanent observatories progressively deployed to measure sea surface elevations (SSE) over a multi-annual scale in various coastal regions. An application of signal processing techniques to relatively highfrequency sea surface height and current velocity time series can thus be particularly useful in identifying the signal spectral components concurring to coastal flooding.

An overview of sea-level variability and trends in the Mediterranean Sea can be found in Gomis et al. (2012) where the highest values of extreme sealevel events, based on 50-year return levels, are found along the Northern Adriatic Sea coast. Furthermore, extended analyses have been conducted for the Adriatic Sea's tides (CushmanRoisin et al., 2001, on the dominant roles of the tidal constituents), storm surges (Pirazzoli and Tomasin, 2002, on the increasing frequency of storm surges), and long term sea-level trends (Vilibić et al., 2017, on the mean sea level changes occurring over centennial to annual timescales).

A recent study by Gomis et al. (2008) examines 44 years (1958-2001) of validated model data for the Mediterranean Sea in order to characterize lowfrequency sea level variability (with the frequency of a seasonal cycle or lower). The spectral analysis revealed the seasonal trend of sea level variability, where the cause was mainly due to variation of atmospheric pressure over the studied region. Highfrequency sea level oscillations (periods of 2 min-6 h) were, on the other hand, studied by Šepic et al. (2015), where data on the signals' characteristics collected with tide gauges were subjected to wavelet analysis (29 stations in the period 2010-2014).

We describe several variations of the spectral analysis and wavelet analysis as methods applicable for the analysis of the SSE in the Mediterranean Sea. Furthermore, we describe the application of these methods to the observations of a particular storm event in the Adriatic Sea and on long-term tide 
gauge measurements available for 62 stations in the rest of the Mediterranean basin.

We hypothesize that by using a combination of described processing techniques to the observed data we will be able to confirm the preliminary results of the existence of a subinertial signal in selected locations within the Mediterranean basin. The obtained results could be used in a further investigation on the origin of a signal, its characteristics, and its possible consequences on the coastal area. The main goal of our investigation was therefore to process the available data by using the selected methods.

\section{In-situ and modelling data analysis}

\subsection{In-situ data collection}

The observations of SSE and current velocities were carried out in Jesolo, a seaside resort near Venice in the NW sector of the Adriatic Sea, a semi-enclosed basin in the eastern Mediterranean Sea (Figure 1, marked as a red square). An acoustic Doppler wave and current profiler (AWAC, Nortek, Rud, Norway) was deployed $800 \mathrm{~m}$ offshore on the seafloor (depth $7 \mathrm{~m}$ ). Current velocity profiles were sampled in 0.50-m cells with a 10-minute frequency and a precision of $0.011 \mathrm{~m} \mathrm{~s}^{-1}$ in the vertical and $0.034 \mathrm{~m}$ $\mathrm{s}^{-1}$ in the horizontal directions. Detailed information on the observations is given in Archetti et al. (2016).

The frequency band of the detected subinertial oscillation was identified by observing an intensive and long-lasting storm event in the North of the Adriatic Sea, at the Jesolo station, in the end of January and the beginning of February 2014, when there was also a documented flooding of the pier in Piran (Bat et al., 2014). During this event a cold air mass from the eastern continental Europe collided with warm and moist air from the northern African coast above the northern Adriatic (Falcieri et al., 2016). The north-easterly (bora) wind in the beginning of the event turned south-easterly (scirocco) for two days, and finally turned back to bora. The average wind speed was $10 \mathrm{~m} \mathrm{~s}^{-1}$ with air temperature changing from the lowest $5{ }^{\circ} \mathrm{C}$ during the bora to the highest $14.5^{\circ} \mathrm{C}$ during the scirocco, while the sea temperature remained constant at approximately $11.5^{\circ} \mathrm{C}$ (Falcieri et al., 2016).

Observations from other available stations in the Mediterranean Sea were analysed to confirm the existence of the detected subinertial signal and explore its spatial extent. The long-term SSE time series were obtained from the tide gauge measurements available at the EMODnet (European Marine Observation and Data Network, http://www.emodnet.eu/) and The National Tidegauge Network (ISPRA), all together for 62 stations in Italy, France and Spain (Figure 1). Additional information concerning the Italian stations can be found on the National Tidegauge Network's official website (http://www.mareografico.it).

The SSE time series at the Italian stations were measured in the period between 2010 and 2018, or at shorter intervals within this period. French and Spanish stations include various durations: from 2 years (Solenzara, 2012-2013) to 16 years at most (Marseille, 1998-2013). The data underwent quality control and we removed all the data with the bad quality flag.

Copernicus model output was used to reassert the observation data and its findings. We used the model output product MEDSEA_ANALYSIS_FORECAST_PHY_006_ 013 (Mediterranean Sea physics analysis and forecast) with metadata provided by the Copernicus-Marine environment monitoring service (Clementi et al., 2019). It is a coupled hydrodynamic-wave model implemented over the entire Mediterranean Basin with horizontal grid resolution of $1 / 24^{\circ}$ and 141 unevenly spaced vertical levels.

\subsection{Applied methods}

Spectral analysis is a common method of decomposing a signal into its harmonic constituents (oscillations) with different periods and amplitudes. It has been applied in physical oceanography since the mid-twentieth century, when spectral approaches were introduced for identifying the properties of sea states under different wind and wave conditions (USACE, 2002). This method can 
be used to isolate sea level oscillations with specific periods. A variation of spectral analysis, called moving-periodogram analysis, is an alternative method to wavelet analysis, which allows an overview on the entire time series at once by subdividing data records into segments and computing the periodograms of each segment. With this feature, it can be used as a preliminary identification of the time intervals with events containing a specific sub-signal, which require a more thorough analysis.

Rotary spectral analysis is a very powerful tool, often used in physical oceanography to detect pulsating signals in vector quantities, which can otherwise be masked by the complexity of the features that normally coexist (and interact) in the ocean. It has been used for decades for studying tidal currents and topographic waves (stemming from the interplay of the effects of rotation and bottom topography). At first, rotary analysis was applied only to the vector components of mooring data (Thompson and Luyten, 1976). The method was subsequently extended to time series of velocity vector fields provided by numerical models (Dukhovskoy et al., 2009), allowing a spatial characterisation of the signal pattern and facilitating its interpretation (Bonaldo et al., 2018).

Wavelet analysis is a variation of Fourier analysis that provides a time-varying spectral estimate of a particular sea state by computing the wavelet coefficients (Holthuijsen, 2007). In addition, it identifies events with considered signal against a random background. This makes this method the best for preliminary signal analysis.

\subsubsection{Spectral analysis}

Spectral analysis of random digital signals is a way of determining the distribution of the signal energy content over its frequency bands. We used the discrete time series $\mathrm{y}\left(\mathrm{t}_{\mathrm{n}}\right)=\mathrm{y}_{\mathrm{n}}$ measured at equally spaced time increments $t_{n}=n \Delta t$, where $\Delta t$ is the 10minute sampling interval (Thomson and Emery, 2014). The maximum frequency that can be resolved from a signal with sampling interval $\Delta \mathrm{t}$ is the so-called Nyquist frequency $f_{N} \equiv 1 /(2 \Delta t)$.

The SSE signal under consideration can therefore be expressed as a discrete Fourier series (Thomson and Emery, 2014):

$Y_{k}=\Delta t \sum_{n=1}^{N} y_{n} e^{-i 2 \pi f_{k} n \Delta t}$

where $\mathrm{N}$ is the number of frequencies $\mathrm{f}_{\mathrm{k}}$ in the Nyquist interval $-f_{N} \leq f_{k} \leq f_{N}$ and:

$f_{k}=\frac{k}{N \Delta t}$

for $k=0, \ldots, N$.

The energy spectral density for a discrete, finiteduration time series $\mathrm{S}_{\mathrm{E}}\left(\mathrm{f}_{\mathrm{k}}\right)$ in the frequency band [ $\mathrm{f}_{\mathrm{k}^{-}}$ $\left.1 / 2 \Delta \mathrm{f}, \mathrm{f}_{\mathrm{k}}+1 / 2 \Delta \mathrm{f}\right]$ around the frequency $f_{k}$ is defined as the square of the modulus of the Fourier transform (Thomson and Emery, 2014):

$S_{E}\left(f_{k}\right)=\left|Y_{k}\right|^{2}$

Finally, the energy spectral density can be expressed in terms of power spectral density as:

$S_{E}\left(f_{k}\right) \approx \frac{s^{2}}{\Delta f}$

where $s^{2}$ is the signal variance over the frequency band $\left[\mathrm{f}_{\mathrm{k}}-\Delta \mathrm{f} / 2, \mathrm{f}_{\mathrm{k}}+\Delta \mathrm{f} / 2\right]$ :

$s^{2}=\int_{f_{k}-\Delta f / 2}^{f_{k}+\Delta f / 2} S_{E}\left(f_{k}\right) d f_{k}$

An estimate of the power spectral density is called a periodogram spectral estimate. In practice, periodograms are computed using a discrete Fourier transform together with zero-padding.

To reduce the discontinuity at the data-set boundary we applied windowing. We selected the Hanning window for smoothing the spurious spectral components arising from the contribution of the extremes in the recording interval (Heinzel et al., 2002).

As the spectral analysis must be conducted on every selected time interval within a time series individually, a less time-consuming method, the moving-periodogram analysis, was applied in order to estimate the time intervals with the strongest signal (Bertoncelj, 2018). The moving-periodogram analysis provides a single diagram for the entire time series in a selected location. It decomposes the 
signal into a set of harmonic components and, as in the spectral analysis, computes the energy spectral density.

For the specific analysis Welch's averaged modified periodogram method of spectral estimation was used (Welch, 1967). This is an improved version of the initial Bartlett's method, where Welch's approach divides the time series data into segments with a selected percentage of overlapping. Hanning windowing is introduced in order to decrease the effect of redundancy stemming from the overlap. The resolution can be improved by properly selected parameters of windowing and overlapping in order to remove noise and minimize the effect of the signal's non-periodicity. In addition, the period of the overlapping window segments must be chosen properly. In the presented analysis we selected the period 90 days and a length of a window 30 days, and the overlay percentage was set to $50 \%$ (Bertoncelj, 2018).

\subsubsection{Rotary spectral analysis}

With the vectorial time series, the analysis of the signal in the frequency domain requires the use of the rotary spectral analysis. A two-dimensional velocity vector $\vec{U}(t)$ is composed of two orthogonal components $u(t)$ and $v(t)$, which in the analysis conducted on the data from the Jesolo station represent the along- and cross-shore components of the vertically-averaged horizontal current velocity.

The vector $\vec{U}(t)$ can be expressed by a discrete Fourier series (Emery and Thomson, 2001):

$\vec{U}(t)=[\overline{u(t)}+i \overline{v(t)}]+\sum_{k=1}^{N}\left[U_{k} \cos \left(\omega_{k} t-\right.\right.$

$\left.\left.\phi_{k}\right)+i V_{k} \cos \left(\omega_{k} t-\theta_{k}\right)\right]$

where $t=N \Delta t$; the angular frequency is denoted by $\omega_{k}=\frac{2 \pi k}{t}$ and $\overline{u(t)}+i \overline{v(t)}$ depicts the mean velocity. The amplitudes of the $k$-th Fourier component are $\mathrm{U}_{\mathrm{k}}$ and $\mathrm{V}_{\mathrm{k}}$ and the phases are denoted by $\phi_{k}$ and $\theta_{k}$ for the real and imaginary components, respectively (Emery and Thomson, 2001).

The two opposite rotary components of the energy spectral density are valid for frequencies $f_{k}=$ $\omega_{k} / 2 \pi$ defined by the counter-clockwise spectra:

$S\left(f_{k}^{+}\right)=S_{k}^{+}=\frac{\left(A_{k}^{+}\right)^{2}}{N \Delta t}$

for the positive frequencies $f_{k}=0, \ldots, \frac{1}{2 \Delta t}$, where $A_{k}^{+}$is the amplitude of a counter-clockwise rotary component of the series, and by the clockwise spectra:

$S\left(f_{k}^{-}\right)=S_{k}^{-}=\frac{\left(A_{k}^{-}\right)^{2}}{N \Delta t}$

for the negative frequencies $f_{k}=\frac{-1}{2 \Delta t}, \ldots, 0$, where $A_{k}^{-}$is the amplitude of a clockwise rotary component of the series.

One-sided rotary spectra are then presented as a function of frequency magnitude $|f| \geq 0$ and both components of the spectra, where the clockwise and counter-clockwise spectra are plotted for negative and for positive frequencies, respectively.

\subsubsection{Wavelet analysis}

Wavelets are wave-like oscillations with localized temporal and frequency information. They can, with a properly selected mathematical function (the socalled mother function that generates the wavelets in terms of translations and dilations of the function), describe the analysed signals.

Wavelet analysis has numerous advantages compared to the more common Fourier analysis, as it can analyse non-stationary signals, where the amplitudes of the signals' frequency components vary in time. Wavelet analysis therefore tries to characterize the signal by localizing the amplitude and phase of each spectral component of the data 
sets under consideration (Emery and Thomson, 2001).

We selected the standard Morlet wavelet $g(t)$ (Thomson and Emery, 2014):

$g(t) \rightarrow g\left[a^{-1}(t-\tau)\right]=$

$\frac{1}{\sqrt{a}} e^{\frac{-1}{2}[(t-\tau) / a]^{2}} \sin [c(t-\tau) / a](10)$

where the function $g$ is a mother wavelet function, $\tau$ is the translation parameter that defines the centre of a wavelet, and $a$ is the scale dilation parameter (Emery and Thomson, 2001). The Morlet wavelet is essentially a sine function (determining the carrier frequency) modulated with a Gaussian peak (determining the envelope of the signal). It progresses through the time series $x(t)$ by increasing the parameter $\tau$ and has the centre of the wavelets at $t=\tau$ (Thomson and Emery, 2014). The scale dilation parameter $a$ influences the width of the Gaussian curve, while parameter $c$ determines the number of oscillations over the span of the function.

The wavelet analysis is a suitable preliminary step in the analysis of relatively long non-stationary time series. By applying this tool one can point out the periodic events with the most intense signal within the desired frequency band. It is therefore the first step in determining the frequency of the harmonic component of the SSE that is being analysed.

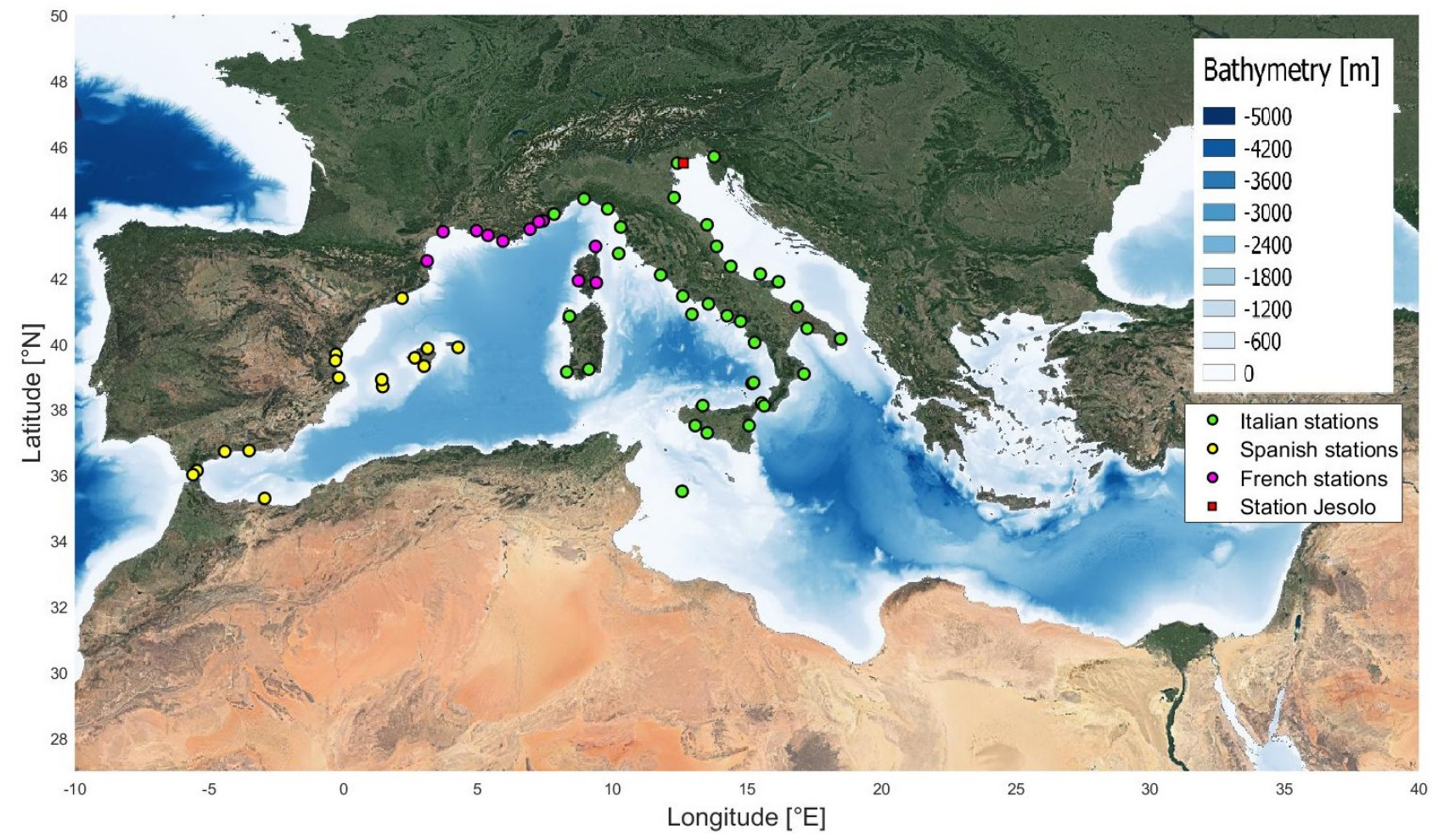

Figure 1: The locations of the tide gauge stations in Italy (green), France (purple) and Spain (yellow) and the location of the acoustic Doppler wave and current profiler in Jesolo near Venice (NW Adriatic Sea), marked as red square (bathymetry data obtained from modelled gridded bathymetry data GEBCO 2019).

Slika 1: Lokacije merilnih postaj v Italiji (zelena), Franciji (vijolična) in Španiji (rumena) ter lokacija akustičnega Dopplerjevega merilnika valov in tokov v Jesolu pri Benetkah (SZ Jadransko morje), označena z rdečim kvadratom (batimetrija pridobljena iz modela batimetrije GEBCO 2019). 


\subsection{Application of methods}

We performed the analyses using: (i) spectral and rotary spectral analyses at the Jesolo station; (ii) wavelet, spectral and moving-periodogram analyses for measured data at the multiple stations along the Mediterranean coast, and; (iii) band pass filtering using the 2nd-order Butterworth filter with low cutoff frequency $=1 / 80$ hours and high cutoff frequency $=1 / 60$ hours on the modelling results.

Preliminary analysis of SSE and current velocities at the Jesolo station for the time window between the end of January and the beginning of February 2014 revealed a peak in the frequency spectrum within the frequency band $0.3-0.4$ day $^{-1}$ (corresponding to a period between 60 and 80 hours). We first computed the signal's energy spectral density on the SSE data from the Jesolo station by using spectral analysis (Bertoncelj, 2018). For analysing the current velocities, we applied the rotary spectral analysis on both horizontal velocity components $u$ and $v$. With these methods we computed the energy spectral density and isolated the frequencies of the signal within the selected frequency band.

After the first-order approximation of a signal at Jesolo station, the analysis was continued in order to identify the temporal and spatial extent of the identified subinertial signal. For this purpose, the measured data from the Mediterranean Sea stations (Figure 1) were analysed using the abovementioned methods (Bertoncelj, 2018). To explore the signal's temporal dimension, we conducted wavelet analysis and spectral analysis on data from a few Italian stations in the Adriatic Sea (Venice, Ravenna, Ancona, and Trieste) (Bertoncelj, 2018). First, the events with the evidenced signal within the selected frequency band $0.3-0.4$ day $^{-1}$ were isolated by performing wavelet analysis. After identifying the events with the strongest signal in the selected frequency band, we conducted spectral analysis and computed the signal's energy spectral density. Its spatial extent was analysed by performing movingperiodogram analysis on data from all available stations.

The data obtained from the Copernicus modelling simulations

product
MEDSEA_ANALYSIS_FORECAST_PHY_006_ 013 was analysed using the wavelet transform analysis on multi-year time series in order to isolate the events with maximum energy density in the subinertial part of the spectrum. For the time windows of interest, the obtained elevation data were band-pass filtered in the time domain over the entire Mediterranean basin.

\section{Results and discussion}

The preliminary data analysis at the Jesolo station between 20 January 2014 and 21 February 2014 showed evidence of a subinertial signal with a period of 60-80 hours for both the current velocities and the SSE. The details of the analysis are given in Bertoncelj (2018). The results of the rotary spectral analysis and the spectral analysis are presented in Figure 2. There, evidence of the signal is present in both diagrams; thus, the consistency of the applied methods is high. Due to the indicated existence of a subinertial signal in the frequency band between 0.3 -0.4 day $^{-1}$ we further investigated this frequency band, first at the Venice station.

In Figure 3 we present an example of a wavelet analysis for the station in Venice (Italy) for the period from 20 January 2012 to 21 February 2012 when the strongest signal was observed (Bertoncelj, 2018). The top diagram shows the raw data and the bottom diagram shows the wavelet coefficients of the time series. The strongest colours in the plots, associated with the higher wavelet coefficients, depict the frequencies with the densest energy. Variance density peaks are evident at the diurnal and semidiurnal tidal frequencies, but can also be noticed in the observed frequency band between 0.3 -0.4 day $^{-1}$.

The wavelet analysis of data from the Venice station in the time interval between 2010 and 2018 showed evidence of a subinertial signal in the frequency band between $0.3-0.4$ day $^{-1}$ at least once per year. The time windows and durations of the signals are presented in Table 1.

Table 1 depicts the temporal occurrence of the subinertial signal. The signal appeared in Venice at least once per year and lasted for at least 10 days. The data in Table 1 also indicate that the subinertial 
signal at the Venice station has always occurred between the beginning of September and the end of May; it has never been observed during the summer.

The same methods were applied to other Italian stations in the Northern Adriatic Sea (Ancona, Ravenna and Trieste). Spectral analysis of these stations also revealed a peak in the frequency band of $0.3-0.4$ day $^{-1}$. This suggests that the occurrence of such a subinertial signal is a common phenomenon throughout the Northern Adriatic Sea. To explore the spatial extent of the signal's occurrence, moving-periodogram analysis was performed on the available SSE time series from the

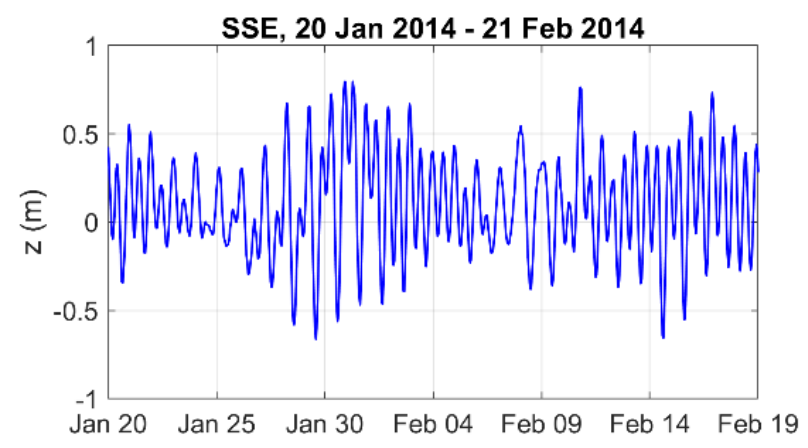

Barotropic velocity, 20 Jan 2014 - 21 Feb 2014

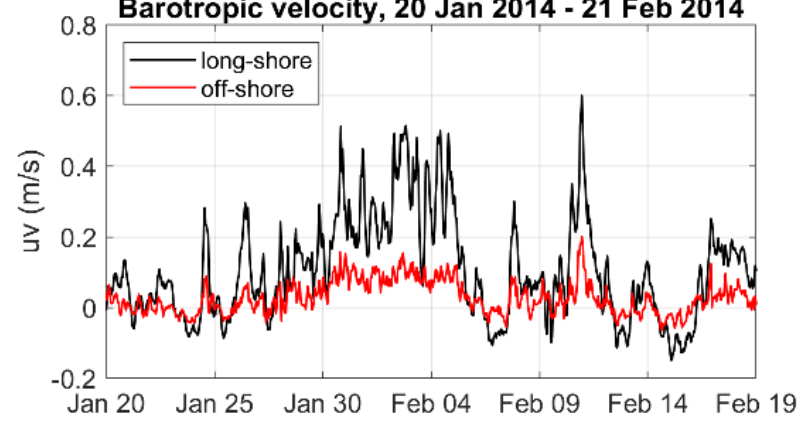

rest of the Mediterranean stations. An example of the auto spectral analysis at the Carloforte station (Italy) is presented in Figure 4. The diurnal and semidiurnal tidal periods are pronounced during the entire time series (excluding the blue periods of the missing data). Furthermore, signals with lower SSE oscillations with periods longer than 1 day are noticeable, among which the presence of a subinertial signal with a period between 60 hours and 80 hours can be noticed in winter months (an example in Figure 4 within the period between December 2012 and April 2013 is denoted with a red circle).
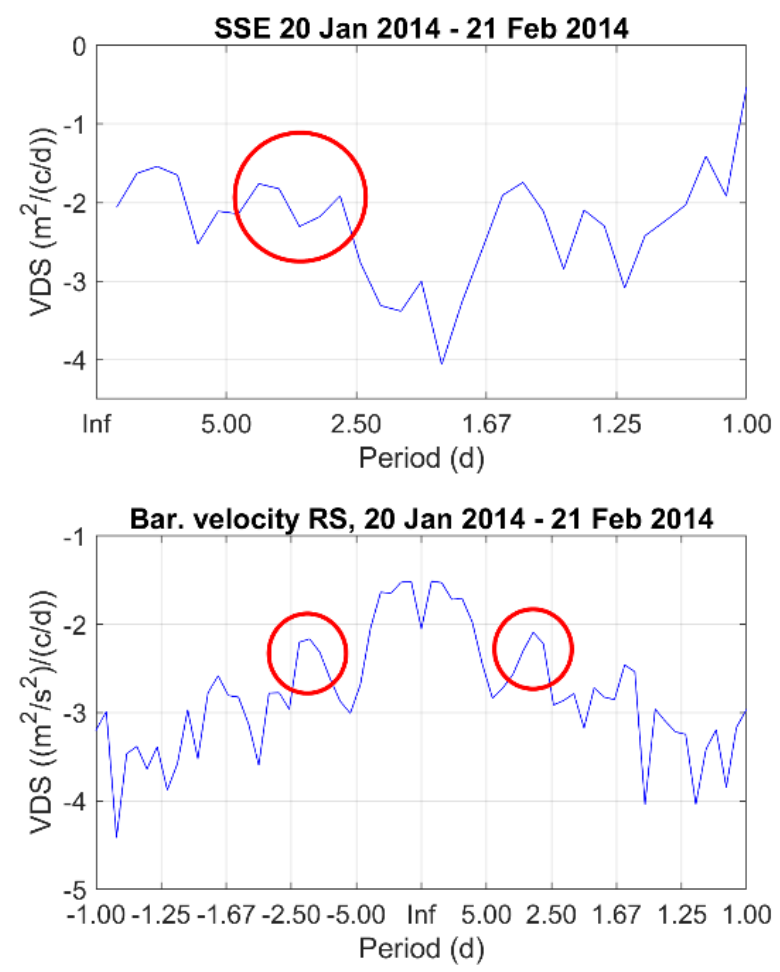

Figure 2: Spectral analysis (top right, VDS = variance density spectrum) and rotary spectral analysis (bottom right, $V D S=$ variance density spectrum) with the sea surface elevation time series (top left) and current velocity time series (bottom left) for the Jesolo station between 20 January 2014 and 21 February 2014. The red circles show the signal in the observed frequency band.

Slika 2: Spektralna analiza (zgoraj desno, VDS = spekter gostote variance) in rotacijska spektralna analiza (spodaj desno, VDS = spekter gostote variance) z nizi nihanja morske gladine (zgoraj levo) in hitrosti tokov (spodaj levo) za postajo Jesolo v obdobju med 20. 1. 2014 in 21. 2. 2014. Signal v opazovanem frekvenčnem pasu je obkrožen z rdečo. 

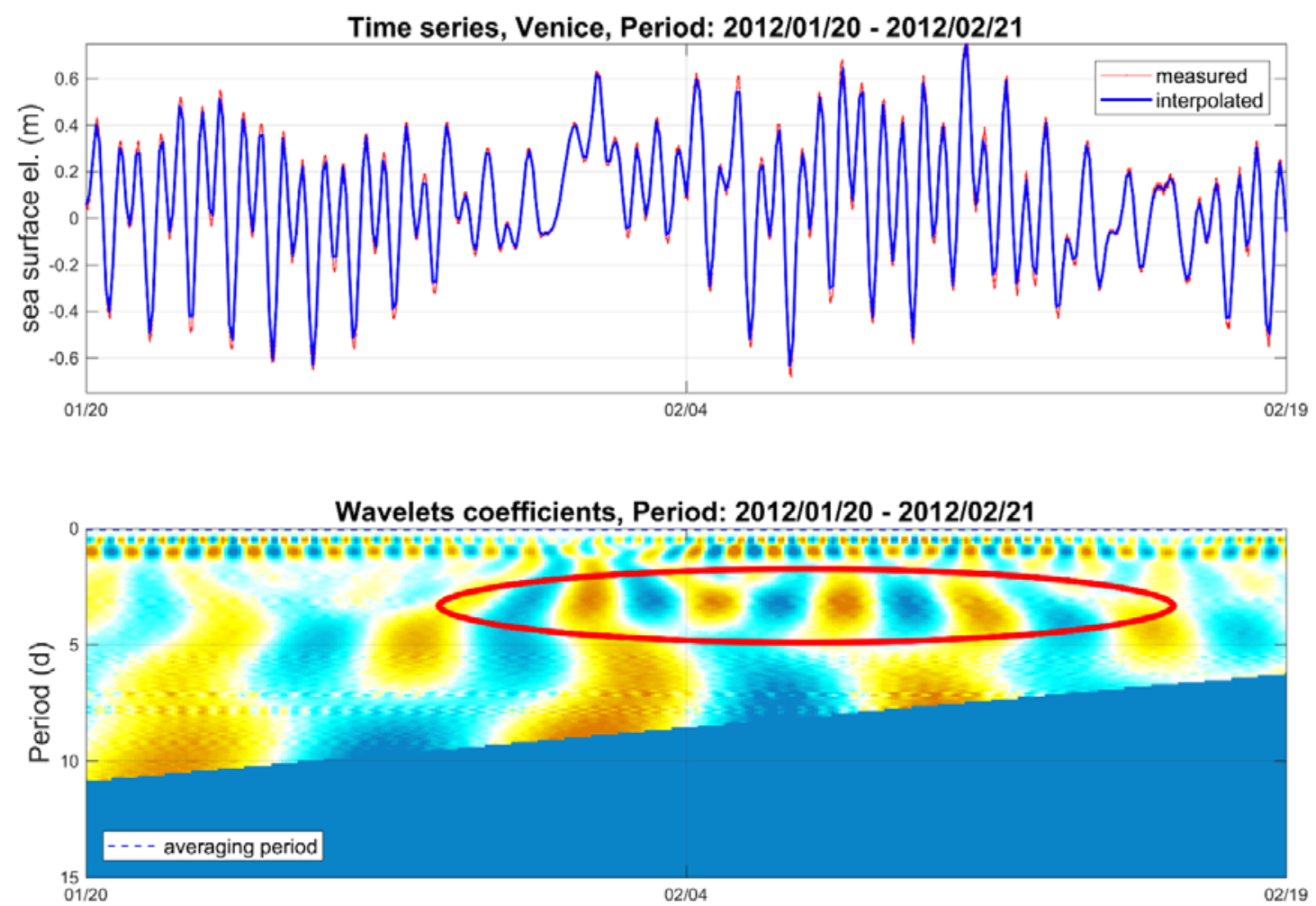

Figure 3: Time series (top) and wavelet transform analysis (bottom) of the sea surface elevations for the station Venice (Italy) between 20 January 2012 and 21 February 2012. The red ellipse indicates higher energy content with a 3-day period during first weeks of February.

Slika 3: Časovni niz (zgoraj) in valčna analiza (spodaj) gladin morja za postajo Benetke (Italija) v obdobju med 20. 1. 2012 in 21. 2. 2012. Rdeča elipsa označuje povišano energijo s periodo 3 dni v prvih tednih februarja.

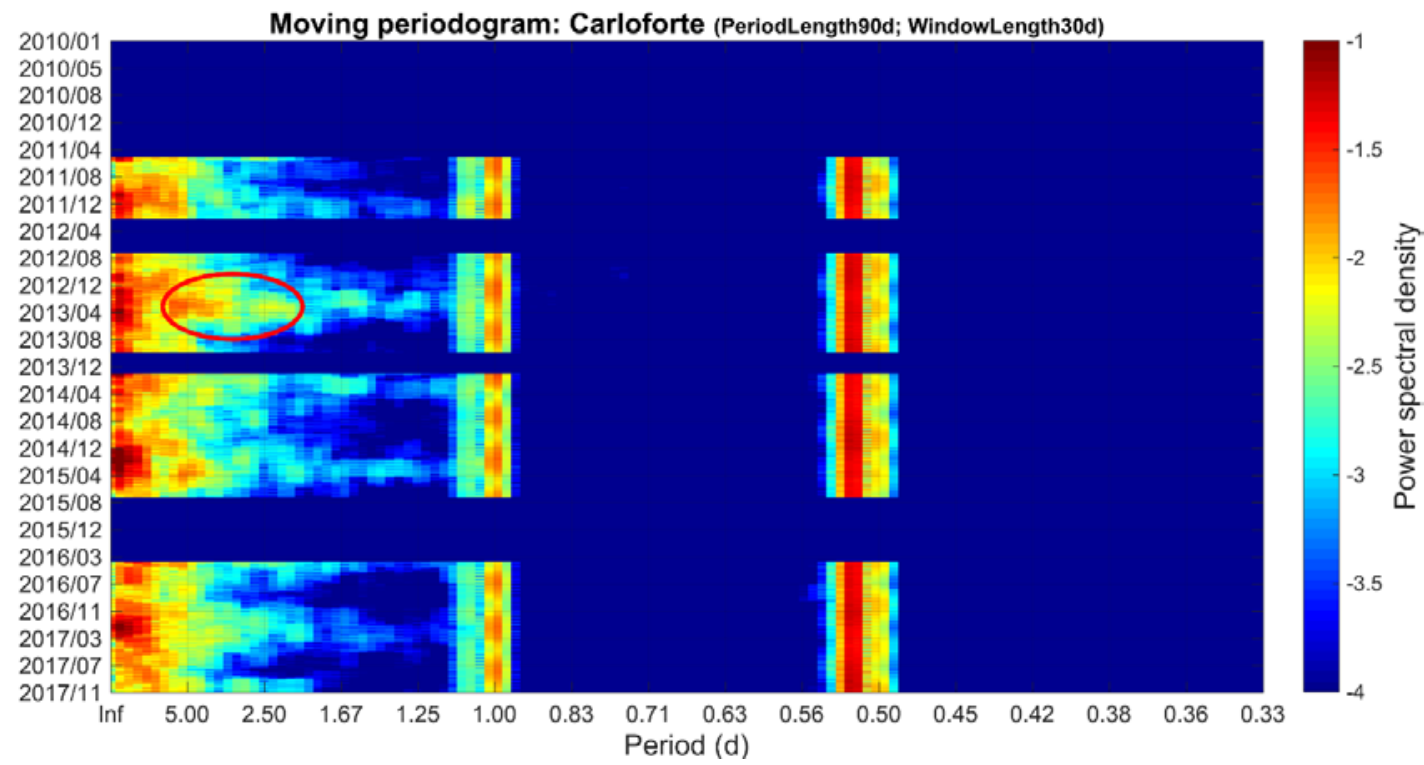

Figure 4: Auto spectral analysis at the Carloforte station (South Sardinia, Italy) for the time series between 2010 and 2017.

Slika 4: Avtospektralna analiza podatkov s postaje Carloforte (Sardinija, Italija) za časovni niz med letoma 2010 in 2017. 
Table 1: Appearance and duration of subinertial signals at the Venice Station (analysed with wavelet analysis). When multiple subsequent signals appear during a period, the duration of each one is reported separately.

Preglednica 1: Pojavljanje in trajanje subinercialnih signalov na postaji Benetke (valčna analiza). Ob več zaporednih signalih $v$ istem obdobju so signali prikazani ločeno.

\begin{tabular}{|c|c|c|}
\hline Year & Period of observation & $\begin{array}{c}\text { Duration of the signal } \\
\text { [days] }\end{array}$ \\
\hline 2010 & 1 January to 15 March & 15 \\
\hline 2011 & 10 February to 25 March & 20 \\
\hline 2012 & 20 January to 21 February & 15 \\
\hline \multirow{2}{*}{2013} & 10 January to 10 March & 30 \\
& 10 March to 25 May & $10 ; 10$ \\
\hline \multirow{2}{*}{2014} & 20 December 2013 to 10 March 2014 & $20 ; 30$ \\
& 20 March to 20 April & 15 \\
\hline \multirow{2}{*}{2015} & 20 December 2014 to 10 March 2015 & $15 ; 10$ \\
\hline \multirow{2}{*}{2016} & 20 March to 5 May & 10 \\
& 15 February to 16 March & $15 ; 10$ \\
\hline \multirow{2}{*}{2017} & 1 October to 1 December & $15 ; 15 ; 10$ \\
& 1 January to 10 March & 20 \\
& 15 April to 25 May & $15 ; 20 ; 30$ \\
\hline
\end{tabular}

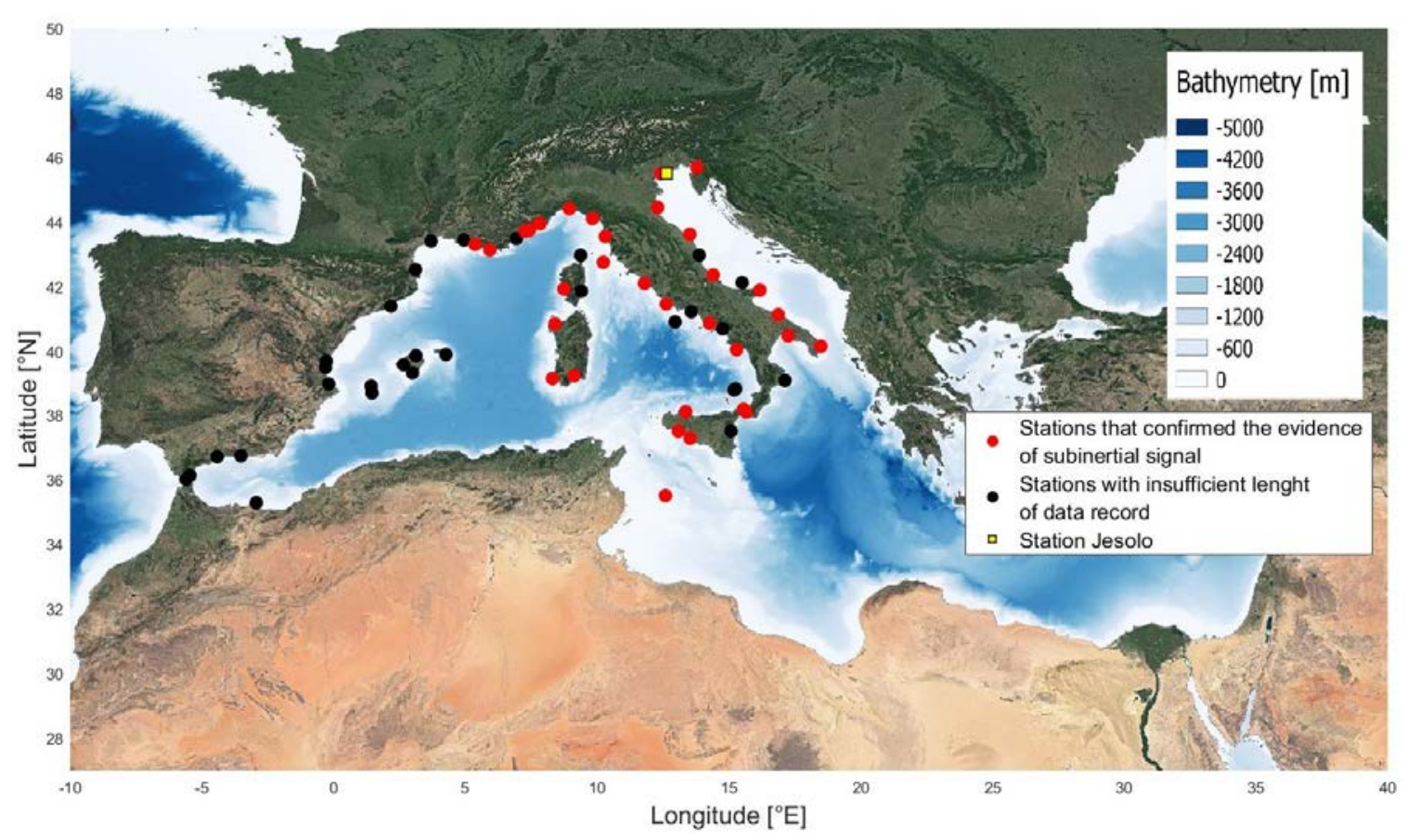

Figure 5: The locations of the tide gauge stations where the presence and seasonality of a signal was identified (red), and the locations of stations with insufficient duration of continuous data records (black). Bathymetry data is obtained from modelled gridded bathymetry data GEBCO 2019.

Slika 5: Lokacije merilnih postaj, kjer je bil signal zaznan (rdeče), in lokacije postaj s prekratkimi časovnimi serijami neprekinjenih meritev (črno). Batimetrija je pridobljena iz batimetričnega modela GEBCO 2019. 
The results of the moving-periodogram analysis indicate the presence of a signal with the frequency band of $0.3-0.4$ day $^{-1}$ for the 32 Mediterranean stations designated with red dots in Figure 5. Data records at 30 stations out of 62 (Figure 1) were inadequate for analysis. Due to discontinuities in the time series we were unable to draw justifiable conclusions, since at least one year of continuous measurements is required for the identification of seasonal occurrence of the signal.

The results of 32 stations in the Mediterranean Sea suggest that the signal is present throughout the Mediterranean Sea. This shows the possible association with barotropic oscillations in the basin. In their study Schwab and Rao (1983) computed the lowest barotropic free mode of oscillation for the Mediterranean Sea to be 38.5 hours. This period corresponds to approximately half of the period of the observed subinertial signal and therefore indicates the possible presence of a free mode oscillation in the signal.

Moreover, Candela and Lozano (1994) investigated the barotropic response of the Western Mediterranean Sea to the observed atmospheric pressure forcing. They found a 2- to 3-times higher response to atmospheric pressure in the winter season. Both the results of the wavelet analysis for the Venice station and the moving-periodogram analysis results of the 32 Mediterranean stations depict the signal's occurrence in the winter season, suggesting atmospheric pressure forcing to be one of the main physical mechanisms driving the subinertial signal.

The presence of the signal was furthermore detected by applying the wavelet analysis on the Copernicus modelling simulations (CMEMS MFS). Figure 6 shows one half-cycle of the subintertial oscillation of the band-passed sea surface height over the Mediterranean basin, together with the band-passed SSE signal in Venice.

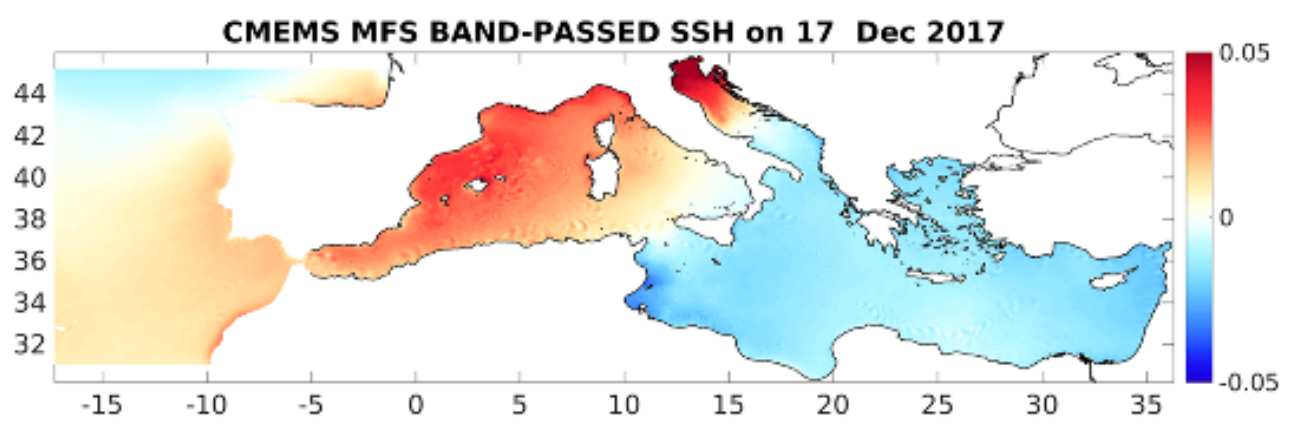

CMEMS MFS BAND-PASSED SSH in VENICE on 17 Dec 2017 00:00

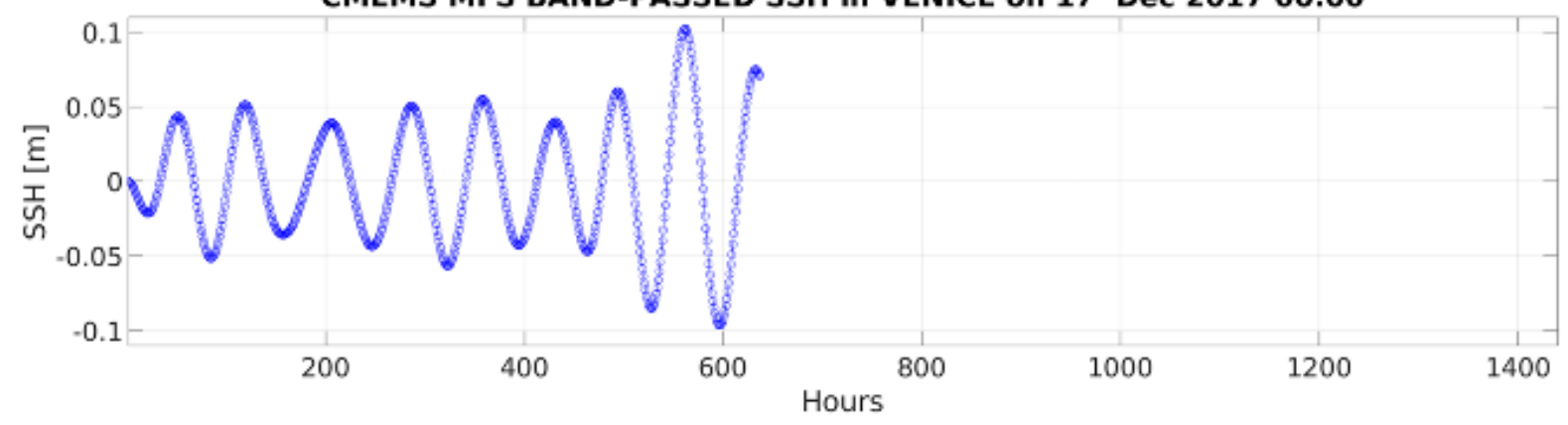

Figure 6: One half-cycle of the subintertial oscillation of the band-passed sea surface height over the Mediterranean basin, together with band-passed SSE signal in Venice. A second-order Butterworth filter was employed with a low-frequency cutoff period of 80 hours and a high-frequency cutoff period of 60 hours.

Slika 6: Polovica cikla subinercialnega nihanja morske gladine v Sredozemskem morju in zaznano nihanje morske gladine v Benetkah. Butterworthov filter drugega reda smo uporabili med frekvenčnima mejama 80 ur in 60 ur. 


\section{Conclusion}

By applying the selected methods, we identified some characteristics of a low-frequency SSE oscillation along the Mediterranean coastline with a subinertial period between 60 and 80 hours. Furthermore, we observed that the signal peaks only occasionally and occurs seasonally. We consider the applied methodology to be adequate for further investigation, as the observed subinertial signal is present regardless of the applied method.

The applied methods proved to be adequate for preliminary analysis as well as for further detailed analyses. The follow-up research should attempt to clarify the mechanisms of subinertial oscillations, their characteristics, and their possible consequences for the coastal area. In order to confirm atmospheric pressure forcing as the main driving mechanism, the analysis of meteorological data of the Mediterranean region as well as of the northern Atlantic region must be performed next. Modelling and forecasting these events constitute a separate problem, which can be better tackled by means of suitable modelling systems coupling atmosphere and ocean dynamics.

\section{References}

Archetti, R., Paci, A., Carniel, S., Bonaldo, D. (2016). Optimal index related to the shoreline dynamics during a storm: The case of Jesolo beach. Natural Hazards and Earth System Sciences, 16(5), 1107-1122. https://10.5194/nhess-16-1107-2016.

Bertoncelj, V. (2018). Low-frequency sea level oscillations in the Mediterranean Sea. Unpublished thesis, University of Ljubljana, Faculty of Civil and Geodetic Engineering.

Bonaldo, D., Orlić, M., Carniel, S. (2018). Framing Continental Shelf Waves in the southern Adriatic Sea, a further flushing factor beyond dense water cascading. Scientific Reports, 8(1), 660. https://10.1038/s41598017-18853-2.

Candela, J., Lozano, C. J. (1994). Barotropic Response of the Western Mediterranean to Observed Atmospheric Pressure Forcing. The Seasonal and Interannual Variability of the Western Mediterranean Sea, Coastal and Estuarine Studies, 46, 325-359.
https://10.1029/CE046.

Clementi, E., Pistoia, J., Escudier, R., Delrosso, D., Drudi, M., Grandi, A., Pinardi, N. (2019). Mediterranean Sea Analysis and Forecast (CMEMS MED-Currents 2016-2019) (Version 1). Copernicus Monitoring Environment Marine Service (CMEMS). doi: https://doi.org/10.25423/CMCC/MEDSEA ANALYSIS _FORECAST_PHY_006_013_EAS5.

Cushman-Roisin, B., Gačić, M., Poulain, P.-M., Artegiani, A. (2001). Physical Oceanography of the Adriatic Sea. Springer-Science+Business Media, B.V. https://10.1007/978-94-015-9819-4.

Dukhovskoy, D. S., Morey, S. L., O’Brien, J. J. (2009). Generation of baroclinic topographic waves by a tropical cyclone impacting a low-latitude continental shelf, Continental Shelf Research, 29(1), 333-351. https://10.1016/j.csr.2008.01.007.

Emery, W. J., Thomson, R. E. (2001). Data analysis methods in physical oceanography. p. 612.

Falcieri, F. M., Kantha, L., Benetazzo, A., Bergamasco, A., Bonaldo, D., Barbariol, F., Malačič, V., Sclavo, M., Carniel, S. (2016). Turbulence observations in the Gulf of Trieste under moderate wind forcing and different water column stratification. Ocean Science, 12(2), 433449. https://10.5194/os-12-433-2016.

Gomis, D., Ruiz, S., Sotillo, M. G., Álvarez-fanjul, E., Terradas, J. (2008). Low frequency Mediterranean sea level variability: The contribution of atmospheric pressure and wind. Global and Planetary Change journal, 63, 215-229. https://10.1016/j.gloplacha.2008.06.005.

Gomis, D., Tsimplis, M., Marcos, M. (2012). The Climate of the Mediterranean Region: Mediterranean Sea-Level Variability and Trends. https://10.1016/B9780-12-416042-2.00004-5.

Heinzel, G., Rüdiger, a, Schilling, R., Hannover, T. (2002). Spectrum and spectral density estimation by the Discrete Fourier transform (DFT), including a comprehensive list of window functions and some new flat-top. Max Plank Institute, 1-84. https://395068.0.

Holthuijsen, L. H. (2007). Waves in oceanic and coastal waters. Cambridge University Press. https://10.1017/CBO9780511618536.

Pirazzoli, P. A., Tomasin, A. (2002). Recent Evolution of Surge-related Events in the Northern Adriatic Area. Journal of Coastal Research, 18(3), 537-554. https://10.4000/mediterranee.174.

Schwab, D. J., Rao, D. B. (1983). Barotropic oscillations 
of the Mediterranean and Adriatic Seas. Tellus, 35A(5), 417-427. https://10.1111/j.1600-0870.1983.tb00216.x.

Sektor za analize in prognoze površinskih voda, Urad za hidrologijo in stanje okolja (2014). Hidrološko poročilo o visokih vodah $\mathrm{v}$ dneh med 30 . januarjem in 3 . februarjem 2014 (Hydrological report on high waters between 30 January and 3 February 2014). pp. 1-8.

Šepic, J., Vilibic, I., Lafon, A., Macheboeuf, L., Ivanovic, Z. (2015). High-frequency sea level oscillations in the Mediterranean and their connection to synoptic patterns. Progress in Oceanography journal, 137, 284-298. https://10.1016/j.pocean.2015.07.005.

Thompson, R. O. R. Y., Luyten, J. R. (1976). Evidence for bottom-trapped topographic Rossby waves from single moorings. Deep Sea Research and Oceanographic Abstracts, 23(7), 629-635. https://10.1016/00117471(76)90005-X.
Thomson, R. E., Emery, W. J. (2014). Data Analysis Methods in Physical Oceanography. Elsevier. https://10.1016/C2010-0-66362-0.

USACE (2002). Coastal Engineering Manual. Engineer Manual 1110-2-1100. Washington, USA.: U.S. Army Corps of Engineers.

Vilibić, I., Šepić, J., Pasarić, M., Orlić, M. (2017). The Adriatic Sea: A Long-Standing Laboratory for Sea Level Studies. Pure and Applied Geophysics. https://10.1007/s00024-017-1625-8.

Welch, P. D. (1967). The use of fast Fourier transform for the estimation of power spectra: A method based on time averaging over short, modified periodograms. IEEE Transactions on Audio and Electroacoustics, 15(2), 7073. https://10.1109/TAU.1967.1161901. 